\title{
EMERSON'S SUPERHERO
}

When, in his hyper-canonical "The American Scholar," Ralph Waldo Emerson asked men (and perhaps women, too) to achieve the condition of "Man Thinking" and resist becoming "the parrots of other men's thinking" (Essays 54), going on to lament that Americans had for too long listened to "the courtly muses of Europe" (Essays70), he was performing an early post-colonial critique of what we may well call the American captive mind. Though to my knowledge Emerson never used the phrase anywhere in his work, one could easily argue that the danger of seeing one's own mind captivated by some force external to the self, was his life-long, obsessive preoccupation. As he put it in the same lecture, "I had better never see a book than to be warped by its attraction clean out of my own orbit, and made a satellite instead of a system. The one thing in the world, of value, is the active soul" (Essays 57). Colonialism, for Emerson, was not only that emanating from European models, which made the "spirit of the American freeman [...] timid, imitative, tame" (Essays 70). When Emerson lamented that writers had "Shakspearized [sic]" for two centuries, he was

1. An earlier version of this essay was presented as a keynote address at the "Captive Minds. Norms, Normativities and the Forms of Tragic Protest in Literature and Cultural Practice," held on September 20-23, 2018, in Szczyrk. I wish to thank Małgorzata Poks and Paweł Jędrzejko for the invitation. I am greatly indebted to Masturah Alatas, who not only discussed at length with me the notion of mental captivity and its use across different disciplinary fields, but also read and commented in detail on an advanced draft of this essay.
Giorgio Mariani RIAS Editor-in-Chief the "Sapienza" University of Rome Italy

(D) 
referring not so much to American writers imitating British models, but to "the English dramatic poets" themselves, who were after all only a symptom of a more general problem affecting people and culture everywhere. "The literature of every nation bear me witness" (Essays 58). For Emerson there is a force we may call 'subliminal colonialism', which is operative not only within one's own culture, but even within one's own self, which can captivate our mind, enslaving it to norms and rules that do not emanate from one's own innermost-or, as Emerson put it in "Self-Reliance," "aboriginal"-self. To quote again from "The American Scholar," "Cenius is always sufficiently the enemy of genius by over influence" (Essays 58).

Even based on such a cursory presentation of Emerson's preoccupation with the self's integrity, it would be possible to draw some connections with Czesław Miłosz's notion of the captive mind, though neither Emerson nor Thoreau nor any other Transcendentalist are anywhere mentioned in Miłosz's book. Notwithstanding the widely different socio-historical contexts their respective work grew out of, both Emerson and Miłosz were troubled by what seems to be a nearly instinctual habit on the part of most human beings to conform to the ruling ideas and concepts of a given historical epoch. Though Emerson lived in what is commonly identified as one of the world's earliest modern democracies, he was aware that the mind could easily

Captive Minds Normativities and Protests become captive also in what was, to a certain extent, a free society. Emerson knew of course that the pre-Civil War United States could not be really called a free country as long as slavery was tolerated, and in a famous (to some infamous) journal entry of 1852, he wrote of having woken up at night "\& bemoaned myself, because I had not thrown myself into this deplorable question of Slavery, which seems to want nothing so much as a few assured voices," adding however that this would mean "my desertion of my post, which has none to guard it but me. I have quite other slaves to free than those negroes, to wit, imprisoned spirits, imprisoned thoughts, far back in the brain of man,-far retired in the heaven of invention, and which, important to the republic of Man, have no watchman, or lover, or defender, but I" (Emerson, Journals 437). According to James Read, "This passage reveals, not indifference toward 
slavery, but instead a fierce battle between two duties, both of which Emerson recognizes as legitimate, and which come into conflict because the time demands of fulfilling each duty are enormous" (161). Whether we agree with Read's defense of Emerson or not, what is worth noting here is that, instead of contrasting his own condition as a free subject to actual physical and political slavery, Emerson worried about the "imprisoned spirits, imprisoned thoughts" which only with an utmost and constant psychological exertion he could hope to liberate. His own mind, if not properly guarded and cultivated, could become captive too, and he too could lapse from the status of Man Thinking to that of the slavish bookworm.

Minds, then, can become captive under totalitarian and authoritarian regimes, where, due to sheer fear or with the scope of securing some personal advantage, individuals pretend to embrace the ideologies of the ruling party. However, from an Emersonian viewpoint, one wonders whether these individuals could be called captives. When one's conformism is merely formal and not substantial, the individual mind would appear to preserve a degree of freedom and even though Emerson would not hesitate to call cowards the people afraid of speaking their minds, he seems far more preoccupied by those who cannot even begin to think because they blindly accept and introject whatever norms and ideas they receive from traditions, books, political leaders, public opinion and other forces. So, before looking more closely at what can be made of Emerson's thinking when it is applied to the context of political protest, I would like to dwell for a while longer on another influential use of the concept of the "captive mind" that is perhaps less familiar to Western scholars, but which I believe is important to mention in this context because it once again raises the issue of the extent to which a mind may remain captive under by and large democratic conditions.

In two articles appearing in the early 1970's in The International Social Science Journal, the Malaysian sociologist Syed Hussein Alatas analyzed at length what he described as the problems created by "the captive mind" to the development of what nowadays we refer to as post-colonial countries. In his essays, Professor Alatas-whose work became more widely known in the West 
Captive Minds Normativities and Protests

after Edward Said discussed it in a key chapter of his own Culture and Imperialism (see Said 245-61)-lamented that an uncritical acceptance of the former colonial powers' ways of seeing, studying, and conceptualizing the world, was hindering the "creative development" of many Asian societies, both culturally and politically. Alatas provides a long list of the defining traits of the "captive mind." I will quote only three entries: "[1] A captive mind is the product of higher institutions of learning, either at home or abroad, whose way of thinking is dominated by Western thought in an imitative and un-critical manner. [2] A captive mind is uncreative and incapable of raising original problems. [...] [3] It is unconscious of its own captivity and the conditioning factors making it what it is" ("Creative development" 691) All this sounds pretty much Emersonian to me, notwithstanding the fact that Alatas never refers to American transcendentalism in his articles. While the Emerson connection has never been explored, scholars and writers have speculated about the extent to which Alatas may have been inspired by Miłosz's widely known book. According to Syed Hussein Alatas' biographer, Masturah Alatas, Miłosz's and S.H. Alatas' captive minds are quite different. The minds of people captivated by the totalitarian Communist regimes of which Miłosz spoke, "were minds at risk if they allowed themselves to remain captive." But at least some of these minds "were still, nevertheless, great minds" (122), she writes in her book, The Life in the Writing. For Professor Alatas, instead, "a captive mind is not a great mind yet because it cannot think creatively and originally, and is held captive by western paradigms of thinking" (Alatas, Life 122). A similar point is made in an essay by Clive Kessler: "The Stalinist apologist of whom Miłosz wrote knew his own situation but was clever enough, and too clever by half, to suppress his knowledge of it, while for Alatas the immobilized postcolonial citizen was blocked culturally and intellectually, only in part by his own consent, from knowing his own situation" (135). On the other hand, when emphasis is placed on the captive mind's unawareness of its own captivity, the resemblance with Emerson is striking. Alatas, like Emerson, is addressing the context of countries whose formal independence is only a few decades old, and rather than simply rejoicing at this newly acquired freedom, very much like Emerson, 
he laments the uncreative spirit infecting the former colonies, and hence their inability to provide original solutions to the cultural, social, and economic problems they are facing. I would not want to push the comparison too far. Emerson's stubborn and irreducible individualism, his praise of "Whim," and his disregard for all forms of "foolish consistency" are always on the verge of flowing into an anarchism that either seems to ignore the need for social cohesion or else is at risk of striking a merely intellectual pose, with little or no purchase on the real world. These are traits that a sociologist and a committed political thinker like Alatas would have had trouble relating to. However, some of Emerson's writings are by no means indifferent to the ethical and political questions that any theory of the captive mind must sooner or later confront. For example, thanks especially to the work done over the last two decades by scholars like Len Gougeon, Emerson's contribution to the anti-slavery and abolitionist movement has been duly emphasized. ${ }^{2}$ Here I want to focus, however, on an aspect of Emerson's work that has received comparatively little attention: his contribution to pacifist and anti-war thinking.

I put the stress on the word thinking because I believe that Emerson's importance lies mostly, if not exclusively, at the level of theory. Unlike Thoreau, Emerson never went to jail for refusing to pay a poll tax in opposition to the Mexican-American War (and slavery). Indeed, many believe it was Emerson himself who paid Thoreau's tax, thus limiting his pupil's prison experience to one single night. Moreover, when the Civil War came, Emerson not only did not oppose it-he was its enthusiastic, perhaps even somewhat cynical supporter. "Ah! sometimes gunpowder smells good" ("Notes" 579), he famously exclaimed in 1861, as he campaigned for "the most absolute abolition" of slavery. Emerson's conversion to the necessity of war-which he did know to be a form of evil-to abolish what he considered the even greater evil of slavery, may have been largely responsible for the neglect visited by scholars on his early essay "War," an address he originally delivered at the invitation of the American Peace society. I have analyzed in some detail this text in my recent book Waging War

2. Besides Gougeon's Virtue's Hero, more generally on Emerson's politics see the essays collected in Levine and Malchuk. 
Captive Minds Normativities and Protests

on War. Peacefighting in American Literature, and I am not going to rehash my entire argument here. I will only say that in the book my main preoccupation was to show how Emerson worked hard to oppose the notion of peace as being synonymous with inaction. "The peace principle"-Emerson explained-"can never be defended, it can never be executed, by cowards. The manhood that has been in war must be transferred to the cause of peace, before war can lose its charm, and peace be venerable to men" ("War" 171). If one looks at this passage from what I would like to call a captive mind perspective-something that I did not do in my book but I would like to do here-it could be argued that in order to emancipate humankind from its tragic fascination with war (a fascination that Emerson explains on both historical and psychological grounds in the early parts of his essay), individuals must first undergo a veritable cultural revolution that would enable them to get rid of the notion that war is something full of charm as well as to understand that peace is fully compatible with what Emerson calls "manhood." The term is unfortunately inescapably masculinist, but I think it could be shown that for Emerson it is not so much connected with being male as with terms such as force, energy, mental and physical prowess. Here Emerson's mind, too, is in part imprisoned by the times' entrenched beliefs, though we should not forget that, from the Enlightenment onwards, pacifists have routinely been accused of being weak, ineffectual, sentimental-in a word, "feminine." Emerson's insistence on the manhood of the anti-war militant, like Mohandas Candhi's belief that peace fighters had to be trained like soldiers and display an even higher courage than the latter, as well as Martin Luther King's own insistence on the power and force of non-violence, are all attempts at sabotaging the deeply held conviction that only through war and violence-paradoxically and ironically enough-can peace be obtained. ${ }^{3}$

Emerson was keenly aware of the contradictory position he was forced to occupy by his argument in favor of peace and against war. He wanted the abolition of war, but he knew that was equivalent to advocating going to war against war.

3. I have analyzed in some detail the Emersonian echoes of Gandhi's ideas about war, violence and non-violence, in the second chapter of Waging War. 
As Kenneth Burke, one of the most brilliant American critical minds of the past century, would put it nearly a century later in one of his perhaps most Emersonian moments, one can never think of war and peace as being "at peace" (Grammar 337). It was both practically and logically impossible. Peace and war could only be "at war," irreducibly opposed to one another. Here was-and it is still with us today-an apparently insoluble challenge for any mind that did not wish to be captive to the lure and "charm" of martial ideas. If, as both the fiercest warmonger and the tamer students of warfare would argue, peoples and nations go to war to secure some kind of "peace"-if, in other words, all wars are at bottom conceptualized as wars to end war-how can we distinguish the "good war" that the anti-war or pacifist thinker wishes to wage on war itself, from the "bad war" of the pro-war camp? At least a partial and tentative answer to this question may be found in the hortatory conclusion of Emerson's "War" essay:

The cause of peace is not the cause of cowardice. If peace is to be defended or preserved for the safety of the luxurious and the timid, it is a sham, and the peace will be base. War is better, and the peace will be broken. If peace is to be maintained, it must be by brave men, who have come up to the same height as the hero, namely, they will carry their life in their hand, and stake it at any instant for their principle, but who have gone one step beyond the hero, and will not seek another man's life; men who have, by their intellectual insight or else by their moral elevation, attained such a perception of their own intrinsic worth that they do not think property or their own body a sufficient good to be saved by such dereliction of principle as treating a man like a sheep. ("War" 174)

Long before Gandhi and King, and with a clarity that not even a thinker much more popular among pacifists like Thoreau would ever achieve, here Emerson laid out the challenge facing the man (or woman) who truly wished to take that perhaps fatal though necessary, "step beyond the hero." Emerson's mind is here trying hard to liberate itself from one concept (that of heroism) not by banning it from its conceptual vocabulary but by redefining it to make room for a different way of looking at the world of strife and conflict. Faced with a situation that Syed Hussein Alatas would describe as one of "intellectual bondage and dependence" "Creative development" 692) on an apparently unshakable tradition, Emerson chooses to proceed through "constructive imitation": he resorts 
Captive Minds Normativities and Protests

to what Kenneth Burke defined as a "homeopathic" approach, which, unlike an allopathic strategy, is based "on the feeling that danger cannot be handled by head-on attack, but must be accommodated" (Attitudes 45n). Hence, rather than rejecting the notion of "heroism" à la Brecht ("Unhappy is the land that needs a hero"), Emerson takes it to a higher level. If the hero is the one who is not afraid to die for one's country and one's beliefs, which hero would be greater than the one who would go into battle ready to risk his life without abdicating his belief in non-violence, and therefore unwilling to stoop so low as to think the salvation of his property or even his own bodily integrity a sufficient cause for hurting others? Killing a man is equivalent "to treating a man like a sheep." The true hero would be the one who, having gone one step beyond the heroes of old, would in fact no longer be called a hero but would be someone for whom no term yet exists. For the time being, we may think of her as a kind of-literally-ultra or super hero, someone who has ventured beyond charted behavioral patterns and embraced a higher moral principle.

Emerson's "War" was written roughly a century before Gandhi, first, and King, a couple of decades later, turned his visionary statement into political practice. Though neither Gandhi nor King (except at the very end of his life, when he took a stand against the U.S. military involvement in Indochina) were primarily engaged in anti-war protests, they were opposing the daily violence which colonialism, racism, and imperialism visited on millions of people belonging to the "darker" races. And they did so, for the most part, asking the protesters they led not to respond to the violence of the army or the police that confronted them. They asked, in other words, not one or two exceptional individuals, but masses of thousands of people to take, in Emerson's terms, "one step beyond the hero," even when they saw their own infants or loved ones brutalized and sometimes murdered before their own eyes. As both King and Gandhi argued, images of this one-way violence would shock world public opinion, and civil rights and independence would be obtained with much less bloodshed than the one following any attempt to put up an armed resistance.

Let me say at once that, much as I admire the unbelievable courage displayed by those who took part in the demonstrations 
in India and the American South, I am not convinced that the strategy of absolute non-violence Emerson theorized, and Gandhi and King tried to apply in actual practice, can always be adequate to redress wrongs, and achieve peace and social justice. Yet, this is not my main concern in this essay. All I wish to emphasize here is that, at the end of the day, not even non-violence can be as violence-free as we may at first think. In other words, while we may believe that, as Emerson put it, once we are unwilling to strike our opponents, no matter how vicious they might be, we resist treating them like sheep, we are in fact ready to let our oppressors treat us like sheep. It is certainly no accident that in his address Emerson resorted to the image of an animal that immediately evokes the scene of sacrifice. One may very well argue that, without ever mentioning him, Emerson is asking us to be like Christ: to rebel, but to do so by accepting that our desire to speak the Truth may force us into the position of the sacrificial lamb. The problem appears to be insoluble. We can renounce violence-we can turn ourselves, our bodies and our minds into a living embodiment of Peace. But as long as we will be struck, maimed, and killed by our oppressors, it is War that will continue to triumph. To the extent that opposition to violence requires a sacrifice of self, it paradoxically reinforces the logic it wishes to escape. All we can do is hope that, by breaking up what René Girard has identified as the circle of mimetic violence, our enemies may be tempted to mirror our behavior: to imitate, that is, our non-violence. ${ }^{4}$ Historically, there have been indeed cases in which non-violence has worked this way. But this is far from being the norm. As the American theologian Kelly Denton-Borhaug has noted in a discussion of how we may find alternatives to the sacrificial system of war, proclaiming one's willingness to die for the cause of peace may be a way to reinforce rather than undermine the logic of sacrifice. This is obviously also the case with Emerson's new "hero," whose renunciation of violence takes on heroic-or better, super-heroic-proportions by virtue of his readiness to become a pacifist martyr.

It is certainly no accident that thinkers as diverse as the afore-mentioned Cirard and Denton-Boraugh, as well as the American

4. See especially his seminal Violence and the Sacred. 
Protestant theologian Walter Wink and the Italian Catholic dissenter Enzo Mazzi, and many others, have all taken issue with the ideology of sacrifice that is generated by the sacrificial reading of the Passion. While many would disagree with Girard's claim that "There is nothing in the Cospels to suggest that the death of Jesus is a sacrifice," there is a broad agreement among Christian pacifist theologians that "The passages that are invoked to justify a sacrificial conception of the Passion both can and should be interpreted with no reference to sacrifice in any of the accepted meanings" (Things Hidden 180). This is no mere terminological dispute. To construct the Passion as a sacrifice that all super-heroic human beings may wish to imitate would entail accepting the inevitability of violence rather than trying to imagine the conditions under which violence may be, if not altogether eliminated, at least contained and moderated. To return to Emerson's superhero, the point is by no means to diminish the extraordinary novelty of his imagined figure, produced by a mind trying to think beyond the commonsense of his day, but simply to suggest that even such a superhero would be at risk of being captivated by an ideology at odds with Emerson's rebellious spirit. The ideology of sacrifice has in fact been historically deployed either to promote war and violence (because, as Cirard has taught us, violence is the sacred) or else to invite people to acquiesce and obey to the powers that be. To put it in different terms, there is no guarantee that even

Captive Minds Normativities and Protests pacifism may not incorporated, paradoxically, in a logic of war.

The lesson to be drawn from the argument I have made thus far is a simple, though hard one. War and Peace need to be constructed as irreducible opposites. They need and must be, to reiterate Kenneth Burke's point, "at war" with one another. To imagine the two "at peace," is to imagine the age-old scenario of war as the only instrument that can guarantee the peace. On the other hand, to imagine the two "at war" means to accept that even peace has something warlike about it, and it cannot claim to be as pure and absolute as we may wish it to be. This is a contradiction, or even better, a foundational antinomy we must accept. We cannot extricate ourselves from such a double-bind, but we can certainly keep our eyes and minds open so that both the violence that is "structural" and internal to any society, and the violence of outright warfare 
that nations deploy against other nations, may be superseded by forms of conflict and disputation from which physical violence may be banned, or banned for the most part. Let me be clear. I am by no means suggesting that anti-war struggles are ineffectual as long as they remain peaceful or, on the contrary, that to wage war on war we must resort to the violence we wish to be free of. The point is rather to acknowledge that, given the inescapably and necessarily conflictual nature of all human societies, the goal of anti-war cultures and practices must be that of transcending the "antagonistic" framework of war by adopting what Chantal Mouffe, in her book Agonistics. Thinking the World Politically, identifies as forms of "agonistic" confrontations that will not erase conflict but will "sublimate" it into a contest between adversaries who respect each other, not enemies whose ultimate desire is to destroy one another. This ideal condition may be described as one of bloodless warfare, or, seen from an opposite perspective, as a form of agonistic peace, and it is indeed an ideal depending on the good will of both sides to settle disputes through dialogue and political negotiations rather than through war and violence. It is a condition that is hard to achieve, but most European nations, after the apocalypse of World War Two, with a series of limitations and contradictions, have been able to achieve it, grosso modo.

"PEACE" LITERATURE

One would be foolish, of course, to ignore that nowadays Europe is threatened by the resurgence of vicious nationalisms, not to mention the increasing structural violence plaguing its societies internally, and which is most visible in the xenophobic sentiments embraced and fanned by many European governments. More generally, one could observe that, far from ushering in an era of everlasting peace, economic globalization has turned out to be largely responsible for sparking armed conflicts in many areas of the planet. Whether one agrees with the notion advanced by Italian political scientist Carlo Galli in La Guerra Globale that "globalization is a world of war" (55, my translation), it would be impossible to deny that, from Africa to the Middle East, from Afghanistan to the Ukraine, the planet is shaken by violence 
Captive Minds Normativities and Protests

and endemic, apparently endless, conflicts. The question of how to oppose war and promote peace is therefore as urgent as ever and it may be symptomatic of this need that over the last few years no less than three major anthologies of pacifist and anti-war writings have appeared in the United States. I cannot discuss these works here in any detail. I do wish, however, to briefly dwell on some general features shared by these anthologies, because they seem to further substantiate the point I have been trying to make so far. To put it bluntly, taken together, these three praiseworthy efforts to create a canon of "peace literature" capable of providing a counter-balance to the much more studied, revered, and popular "war literature," offer a literal textbook demonstration of the thesis I have presented here concerning the impossibility-in both theory and practice-to think the tension between "peace" and "war" as an absolute opposition. As I hope to have shown in my observations on Emerson's (and others') attempt to forge an alternative to the war-peace dichotomy, it is well-nigh impossible to trace a clear-cut, insurmountable line between these two concepts, just as it is hard at times to understand where non-violence ends, and violence begins. The idea of "peace" that emerges from these three anthologies is deeply conflictual. What these works suggest, I propose, is that peace must be defined as the real movement which, to abolish the present state of war, must be itself pugnacious, courageous, and ultimately willing to take that daring, dangerous "step beyond the hero" we have so far discussed. At the same time, however, the writings collected in these volumes offer a clear indication of how, historically regarded, anti-war movements have been anything but struggles of Beautiful Souls against an Ugly World.

The intention animating the collections under consideration is perhaps no better illustrated than in one of Bill Watterson's "Calvin and Hobbes" comic strips reprinted on page 621 of Lawrence Rosenwald's War No More. Three Centuries of American Antiwar o Peace Writing, the richest of the "peace literature" anthologies I just mentioned. The widely known characters created by Watterson are a six-year old boy named Calvin, and his stuffed tiger Hobbes, who in Calvin's imagination is a living, speaking being, endowed with his own independent personality. In the first table 
of the strip, Hobbes asks an equally helmeted Calvin, "How come we play war and not peace?." This question is answered by Calvin with a sagacity that goes well beyond his supposedly infantile consciousness: "Too few role models." As Rosenwald writes in introducing the strip, "Anyone making an anthology like this one is responding to the problem Calvin identifies, and hoping to offer a partial remedy: to help people learn how to "play peace" if they so desire" (621). Since we learn how to play a game by imitating those who are already experienced players, the role of a "peace literature" canon must necessarily be that of providing inspirational models even though, as will become clear in a moment, the models showcased by the three volumes differ widely not only because of their respective historical groundings, but also in terms of temperament, ideological affiliations, and, most importantly perhaps, of the position they occupy along the continuum running-to resort to Duane L. Cady's useful terminology-from Warism to Pacifism.

All three anthologies put on full display, rather than hide, the contradictions and ambivalences around which they are built. We Who Dared to Say No to War. American Antiwar Writing from 1812 to Now, published in 2008, is the outcome of the collaboration between a scholar from the Left (Murray Polner) and a Conservative (Thomas E. Woods, Jr.). This is an interesting choice because, first, it calls into question the belief that anti-war thinking is an exclusive prerogative of the Left, and, second, it makes room for a substantial number of anti-war pronouncements which have come from the Right. This ideological openness is to be found also in the other two collections. For example, both Not in Our Name. American Antiwar Speeches, 1846 to the Present, edited by Jesse Stellato, and War No More, which published Barack Obama's 2003 speech against Ceorge W. Bush's "dumb war" against Iraq, as well as Senator Robert Byrd's elegant oration against the same war. These two texts are also printed in the Murray and Woods anthology and, at this point may well be defined as "classic" anti-war addresses. I can easily imagine many objecting to the inclusion of figures like Obama-the president who continued the Afghanistan war, who helped tear apart Libya, and who master-minded the drones' war-and Byrd, a conservative Democrat who, in his youth joined the Ku Klux Klan (which he later regretted), and also supported 
Captive Minds Normativities and Protests

with no hesitation the Vietnam War (and, of this he never repented). What is perhaps the unintended goal of these anthologies is to show that, when we look closely at the historical record, many anti-war militants were by no means absolute pacifists, and even the absolute pacifists were, at times, either ambivalent about the morality of their position or else stood accused of being interested in saving only their own personal sense of morality, regardless of their choices' practical consequences. As you see, Emerson is by no means an exception. Many others were sincere in loving peace but found that under certain conditions such an inclination could not be followed through.

In sum, not all the "role models" found in the pages of these three impressive collections are some version of Emerson's pacifist superhero. Some authors do live up, or struggle to live up to that ideal. Think for example of all those, from Eugene Debs to Bayard Rustin, from Don Benedict to the Berrigan brothers, who spent time in prison for resisting war and the draft. Yet, many are the men and women whose choices were often circumstantial, and who, like former U.S. president Barack Obama, not only were selective in their opposition to war, but never tried to hide this fact. If one reads carefully his Nobel Peace Prize acceptance speech-a text understandably not reprinted in any of these three anthologies, because, notwithstanding the occasion and the obligatory nods to Martin Luther King, it is no anti-war address but actually an argument in favor of "just wars"-one realizes that to call Obama a hypocrite will not do. One may be-like I am-very critical of his presidential conduct both at home and especially abroad, but Obama, like many other authors who appear in these anthologies, would most likely contend that "absolute pacifism" of the kind preached by the early Emerson, in its Christ-like purity, is, regrettably, not always applicable.

We may, as I already noted, be troubled at seeing separated by only a few pages authors as different as, on the one hand, Dwight D. Eisenhower-who was Supreme Commander of the Allied Forces in Europe during World War Two-and, on the other hand, Don Benedict and David Dellinger, who served harsh prison sentences for refusing to serve in Eisenhower's army. And yet, not only the latter's denunciation of the "military-industrial complex" has become 
a text often quoted by anti-war and left-wing activists all over the world, but many contemporary anti-war writers and militants may be-ironically enough-more sympathetic to Eisenhower than to those pacifists who, like Dellinger or Bayard Rustin, believed that not even the fight against the Nazi and Fascist menace justified going to war. Of course, when one reads about the prison ordeal of a young man from a very rich family like David Dellinger, who, as he put it, "went straight from Yale to jail" because, like fellow war-resister Milton Meyer, he considered war to be the essence of Fascism, it is difficult not to admire his commitment to the pacifist ideal. No serious reader would dare call Dellinger a coward for refusing to serve in the so-called "Cood War." Indeed, he would certainly be a fit candidate for the role of Emersonian superhero. However, the book that has most recently defended pacifist and anti-war activity in the West before and during the early phases of World War Two-Nicholson Baker's Human Smoke-has been attacked by commentators on the Right, the Center, and the Left. In fact, the Baker essay reprinted in the Rosenwald anthology and devoted to "The Dangerous Myth of The Good War" (Rosenwald 736-55) was originally written also as a response to Katha Pollit, who, in the widely-circulated leftist U.S. magazine The Nation, had confessed, after reading Baker's book, the she "felt something [she] had never felt before: fury at pacifists."

World War Two is of course an ultimate test case for both pacifists and anti-war thinkers, because if not a "Cood War" it would seem to come pretty close to be the ideal "just war." No wonder that in his essay Baker refers to it as "pacifism's great smoking counterexample," the archetype invoked whenever America decides that a new "Hitler" like Saddam Hussein, Slobodan Milošević, or Osama Bin Laden looms on the horizon and must be confronted with military force. However, even granting that from the Allied perspective the jus ad bellum during World War Two was unimpeachable, this still leaves open the question of the jus in bello-of the way in which Great Britain and the U.S. conducted the war. ${ }^{5}$ Baker's controversial book raises several objections regarding not only the morality of the relentless pounding and eventual fire-bombing

5. These concepts are elucidated in Michael Walzer's classic Wars Just and Unjust. 
Captive Minds

Normativities and Protests

of Cerman cities but is also skeptical regarding their effectiveness. The Allied air-raids were objectively as savage as the German Blitz on London, and to boot, as a member of Churchill's cabinet observed as early as 1941, "Bombing does NOT affect German morale." On the other hand, as Ceneral Raymond Lee argued, it was good for "The morale of the British people [...] if the bombing stopped, their spirit would immediately suffer" (Baker 434). Now, any criticism of how the Allies fought the war is likely to elicit reductio ad hitlerum counterarguments, as if questioning, say, the firebombing of German cities is tantamount to arguing that Hitler and Churchill were war criminals of the same ilk. They obviously were not, and it strikes me as somewhat intellectually dishonest to argue that this is what Baker wishes to suggest. This is not to say, however, that we should not feel free to investigate the morality of the Allied conduct of the war, and more so precisely because, since the fall of the Soviet empire, references to World War Two have constantly been employed to provide the moral capital necessary to promote the wars waged by the U.S. and its allies.

There is also a more general question that is worth asking given the present essay's focus on issues of mental captivity. How useful is a theory of the "captive mind" to discuss these thorny, perhaps undecidable problems? As has been the case with all wars, immediately before and during the Second World War pacifist and anti-war militants split into different factions. Absolute pacifists like David Dellinger and Bayard Rustin could have easily claimed that those who converted to the necessity of opposing militarily the Nazi-Fascist barbarity had been too easily seduced by the appeal of the very martial ideologies they had formerly pledged to resist. But for the interventionist front, the minds of absolute pacifists were imprisoned in an ideal which, under the circumstances, could not bring about the peace and justice they all desired. I think it is to the credit of thinkers and activists like Dellinger and Rustin that they hardly accused their former comrades of betrayal. They stuck to their principles and paid a very heavy price for doing it, but while they defended their choices both in writing and in practice, they did so without striking any fundamentalist pose. They qualify as Emersonian superheroes not only because they did not respond violently 
to the violence of the state that imprisoned them, and to the jailers who taunted or beat them, but most importantly because they believed they had first and foremost to answer to their conscience. This, however, should not blind us to the fact that along with many who went to war simply because that is what they were told to do by the state, there were several who chose to go only after a period of torturous self-scrutiny. The passages in the Rosenwald anthology from Don Benedict's Born Again Radical are both exemplary and moving in this regard. "Coming out of a quarantine as a known pacifist serving my second term," he writes, Benedict was assailed by doubts regarding the correctness of his decision not to serve. Placed under confinement, he ruminates that "Violence ought not to be stopped by violence.... Nevertheless, my belief in pacifism as an absolute was shaken. How could I stay in solitary if I was unsure that what I was doing was right? What if I were wrong?" (Rosenwald 595). After spending 366 days in the Danbury Federal Correction Institute, in 1943 he finally enlisted in the Army Air Corps, serving in the South Pacific. As he recalled the moment of leaving the prison, many years later, he wrote: "Something fine was being left behind. Also certitude. Also my youth. I knew I would never come back" (Rosenwald 595). Benedict did not claim to have finally found the right answer to his dilemma. In fact, he claims that "certitude" left him the moment he chose to give up on his protest. He went on to fight, but his doubts and his uncertainties were not left behind. This is perhaps the ultimate sign of a mind that is not captive-the mind that knows that its own freedom is always questionable; the mind that knows that Thinking, with an Emersonian capital T, means also to think against itself. The only way to avoid intellectual bondage, that is, is to leave always within one's mind some room for doubt.

If we think of the non-captive mind as one which, while holding fast to some basic moral principles, is endlessly, even mercilessly scrutinizing itself-as a "mind on fire," to quote the title of Robert Richardson's intellectual biography of Emerson-many (though by no means not all) of the writings collected in these anthologies, for all their passionate and unswerving commitment to the cause of peace, would also deserve to be identified as exercises in what Herman Melville's Ishmael would have called "earnest thinking," 
Captive Minds Normativities and Protests

which "is but the intrepid effort of the soul to keep the open independence of her sea" (97). I don't know whether, as Rosenwald writes, the letters exchanged by Yvonne Dilling and Mary Jo Bowman (two Christian activists participating in the anti-imperialist movement in Central America at the time of the Sandinista revolution), are "the greatest American conversation on violence" (Rosenwald 567). Yet there is no question that they comprise an exemplary dialogue in which, their different views notwithstanding, the two writers always contemplate the possibility of being wrong about their choices. If both share the belief that a rigorous Christian vision is irreconcilable with an instrumental conception of violence, Dilling, working in close contact with the Sandinistas, realizes that no matter how theoretically reprehensible, armed resistance seems at times inescapable. Bowman, on her part, does not answer by simply reiterating the dogmas of non-violence, and she is willing to acknowledge that these, too, have their limits. At times she even comforts her friend, writing, "I doubt that any of the classical proponents of nonviolence on your list would condemn the use of armed confrontation in a desperate resistance to tyranny" (Rosenwald 580). She respects her friend's agonizing self-doubting, but she also warns her (rightly, to my mind) about the danger of a revolutionary rhetoric equating the revolution with the coming of the Kingdom of Cod. She is particularly troubled by the legendary poet and revolutionary Trappist monk Ernesto Cardenal's argument about armed struggle being not only an instrument of justice but an act of love. "Is it possible"-Bowman wonders without irony - "to love one's enemies by killing them?" (Rosenwald 581).

Though she is less willing than her interlocutor to set aside her belief in the principle of non-violence, Bowman knows all too well she cannot extricate herself from the condition in which both history and her own personal vicissitudes have placed her. She does not think even for a moment that by sticking to what her conscience tells her, she is thereby innocent of the violence around her:

In a very real sense there is blood on my hands, my bloody pacifist hands. I am guilty of murder. Forgive me if I seem to overdramatize, but consider this: our federal tax dollars have been used time and again to fund 
thousands of atrocities.... I have never carried a gun [...] but my money has supported and my silence has allowed some of the most brutal violence in the history of the world....

The more I allow myself to face that truth about my participation in a violent world, the more my faith and my intellect call me to humility and compassion rather than to doctrinaire ethics. I cannot hope for a clear conscience. I can only hope that my ethical choices are motivated by love rather than fear....

The crucial question is .... What does it mean to hold up Jesus' model of resisting evil by dying rather than killing, amidst a world so permeated with violence-whether it be verbal threats on the streets, psychological violence done to minorities, institutionalized violence inflicted on the unemployed, or bombings plotted to counter Central American insurrectionists? (Rosenwald 583)

As Bowman insists, the condition of "peace" enjoyed by those who are not actively involved in violent actions can hardly absolve them from the obligation to question their "passive" participation in the systemic-structural violence around them. To her credit, it is Bowman herself-the one less willing to give up on non-violencewho formulates the sharpest critique of "peacetime pacifism": "I know that a pacifism untested is an affront to those who suffer. I must take sides, on behalf of the victims of the oppressive powers. I must either be willing to take on suffering or keep my mouth shut" (Rosenwald 584).

\section{TRAGIC CHOICES?}

The adjective that first comes to mind to describe the dilemmas that serious war resisters had to face and the impossibly difficult choices they had to make is, I suppose, "tragic." And as the fate of both King and Gandhi attests, the ranks of peace warriors have indeed suffered tragic losses. This is not surprising since at the heart of tragedy there is conflict and conflict is what any form of protest-including, as I have insisted, peaceful protest-is bound to fuel. Though I think it would be an exaggeration to say that all protest has at bottom a tragic character, protest of the kind Emerson had in mind in his "War" essay, or Thoreau envisioned when he called for our lives to be the "a counter-friction to stop the machine [of government]" ("Civil Disobedience" in Rosenwald 73) can indeed be tragic. Whenever we feel we must put at stake our own 
Captive Minds

Normativities and Protests

lives in defense of a just cause, our protest would seem to take on a tragic character. One might argue that also facing the possibility of being jailed, exposed to police brutality, or simply dealing constantly with the hostility or the indifference of our fellow citizens are all unpleasant consequences a protester or dissenter must face, though I would not consider all these circumstances "tragic," or tragic in the same degree.

In what I have just said, I have used the terms "tragedy" and "tragic" as referring in a general way to sad, painful events involving death or suffering. What I would now like to do, however, is investigate what happens if we adopt a more technical use of these terms. To do so, I will draw on an example from literary history. Building on Thomas Mann's idea that the centrality of tragedy in modern German culture was a consequence of a weak national state, literary scholar Franco Moretti has written that this condition resulted not only in "a tragic version of political struggle" but also "ii]n the notion of conflict as something which must inevitably lead to a crisis, and of crisis as the moment of truth" (253). In Moretti's view, the world of modern tragedy-the world of Ibsen and Strindberg, to quote two notable examples-stands in opposition to the world of the novel, where there is no single "moment of truth." In his view, that of the novel is the world of bourgeois compromise, a social environment of conversation and conventions, with no apocalyptic flashes or revelatory crises. "The interdependence of truth and crisis in tragedy," instead, paves the ground in Moretti's view for "the classical rhetoric of revolutionary politics" (258), which he sees exemplified in Georges Sorel's Réflexions sur la violence, with its theory of the General Strike. "The superior 'morality' of the General Strike-Moretti argues-lies in its forcing social actors to their ultimate forgotten 'truth'. It is never conceived by Sorel as a process (as in Rosa Luxemburg's roughly contemporary writings), but as a single, 'instantaneous' event. As an Apocalypse: the Moment of Truth" (258-59). It is a sad though well-known fact, Moretti adds, that the "tragic image of revolution as the Moment of Truth-with the inevitable corollary that social truth can only emerge in the crisis of a civil war" (259) found admirers on both the Left and the Right. To those who would accuse him of implying that Right and Left 
share the same culture, Moretti replies that this is by no means his point. What he is arguing, instead, is that "it is virtually impossible to extricate the Left from the Right whenever the Left adopts a 'tragic' worldview" (260). A non-tragic world view is not, however, one that necessarily excludes the possibility of revolution or other moments of crisis. It is, instead, one that would consider "the moment of crisis neither as the only moment of truth, nor as the moment of the only truth" (260).

As Moretti writes in the penultimate paragraph of his essay, his concern with these matters is by no means only literary or theoretical, as his example of a Left adopting a tragic worldview is no other than Italian left-wing terrorism, a destructive and self-destructive phenomenon that has left a deep scar on his (which is also my) generation. The "supposed uniqueness" of the revolutionary crisis, "in its superstitious intractability [...] blinded us to the reality of much of the world around us, because it suggested that it was a 'false' world, an untrue one. In order to escape its misleading appearances, we basically had to make our way, no matter how, towards the moment of crisis, and then Social Truth would finally emerge in all its unequivocal clarity" (261). Here lies the fatal flaw of the tragic worldview: the naïve belief that the enormous complexity of our social universe may be transcended by finding some "unique" critical juncture that would allow us to bring down the whole edifice of lies, deceits, and compromises that clouds our vision. My readers may wonder at this point why I dwell on a notion of the tragic that may well be relevant to the context of terrorism but would seem to have little to do with the forms of protest I have been discussing in this essay. The reason is twofold. To begin with, a fascination with the tragic may infect even pacifist and anti-war thinking. For example, Emerson's moment of revelation, which has been so important to my argument, could also be constructed as one of fanatical pacifist martyrdom in which only the superhero can attain a Truth unavailable to those who lack her courage. To the extent that, as I mentioned earlier, a sacrificial aura continues to hover over Emerson's passage, the temptation to see political protest as a moment of personal redemption should never be discounted. The consequences of this may not be even remotely 
Captive Minds

Normativities and Protests

as tragic as the ones deriving from the embrace of terrorism, but to expect super-heroic qualities from masses of people may be unrealistic and counterproductive. Sacrifices like the ones Gandhi and King asked for may be possible only under exceptional conditions and in any case should not be imagined as a value in itself (how could the willingness to be clubbed or shot at, be perceived as a value?) but as the possible consequence of a set of valuesthe ideal of non-violence-upheld in very specific circumstances (cfr. Moretti 260).

The second reason has to do with the need not to see the complex, and as we have seen, at times self-lacerating choices anti-war militants had to make, as "tragic" ones. When Mary Jo Bowman had to decide whether to embrace or resist an armed revolution, and when Don Benedict, in his solitary confinement, literally tortured his own soul wondering whether he had to join the Allied cause or not, we may be tempted to say that they were confronted with "tragic" choices. They both felt they could not, at one and the same time, hold on to the imperative of non-violence and the need to alleviate the suffering of those they wished to save. But, in fact, their predicament was far from the tragic one Moretti describes. If a tragic worldview is one that sees the moment of crisis as the moment of truth, then the crises experienced by militants like Bowman and Benedict were anything but tragic, as they did not end in some moment of illumination. Quite the opposite. Benedict tells us that it is precisely "certitude" that he lost as he left the jail to join the army, and, consequently, also a life of doubt. Bowman, on her part, ends with silence, wondering whether she should simply "shut up." She has made a choice, but she is by no means sure that it is the right choice. We could be no farther from the scenario of apocalyptic illuminations which, according to Moretti, is a feature of modern tragedy. The decisions taken by both Benedict and Bowman are based-as they know all too well-on a form of moral compromise which is the opposite of the tragic devotion to an uncompromising Truth. Bowman and Benedict simply do not know whether they will be more morally correct and politically effective by sticking to non-violence or by giving it up. They have no way of predicting which choice will yield the most desirable results. Theirs is not a choice between 
courage and cowardice, but one between two different ways of displaying their courage.

To reject the notion of political protest as a form of tragedy, therefore, is not to say that those who fight for peace and social justice will not be faced with difficult, at times very painful choices, nor to suggest that-because they cannot be altogether sure of the moral ground on which one stands-their opposition to the status quo would only be weak and tentative. Just because we remain open to the possibility that our choice may not be the most appropriate or effective one, does not mean we should not stand by it with all our hearts and minds. It simply means that we should act responsibly but not fanatically. Most importantly, perhaps, it means that we need to acknowledge that we live in a world in which many different historical, social, and cultural conditions coexist, requiring a variety of differently nuanced approaches to be amended. As far as one of the questions that has preoccupied me the most in this essay-that of the relationhip between violence and non-violence-I would like to conclude by quoting a passage from an essay by Simon Critchley which I think captures much of what I have been trying to argue:

There are contexts where a difficult pacifism that negotiates the limits of violence might be enough. But [...] there are also contexts, multiple contexts, too depressingly many to mention, where nonviolent resistance is simply crushed by the forces of the state, the police, and the military. In such contexts, the line separating nonviolent warfare and violent action has to be crossed. Politics is always a question of local conditions, of local struggles and local victories. To judge the multiplicity of such struggles on the basis of an abstract conception of nonviolence is to risk dogmatic blindness (239).

The risk we face, in other words, is that of letting our mind become captive once again. Emerson himself wrote in "The Uses of Great Men" that "every hero becomes a bore at last" (Essays 627) Under given circumstances, perhaps, even a superhero may not be our best role model. 
WORKS CITED

Alatas, Masturah. Syed Hussein Alatas: The Life in the Writing. Marshall Cavendish, 2010.

Alatas, Syed Hussein. "The Captive Mind in Development Studies." International Social Science Journal, vol. XXIV, no. 1, 1972, pp. 9-25.

------. "The Captive Mind and Creative Development." International Social Science Journal, vol. XXVI, no. 4, 1974, pp. 691-700.

Baker, Nicholson. Human Smoke: The Beginnings of World War II, the End of Civilization. Simon \& Schuster, 2008.

Burke, Kenneth. Attitudes Towards History. U of California P, 1984.

. A Grammar of Motives. U of California P, 1969.

Cady, Duane L. From Warism to Pacifism: A Moral Continuum. Temple UP, 2010.

Critchley, Simon. "Nonviolent Violence." The Faith of the Faithless: Experiments in Political Theology. Verso, 2012, pp. 207-45.

Denton-Borhaug, Kelly. U.S. War-Culture, Sacrifice and Salvation. Equinox, 2011.

Emerson, Ralph Waldo. Emerson in His Journals. Edited by Joel Porte. Harvard University Press, 1982

Captive Minds Normativities and Protests
. Essays and Poems. The Library of America, 1996.

------. "Notes." The Complete Works of Ralph Waldo Emerson, vol. 11, Houghton Mifflin, 1904, pp. 547-648.

------. "War." The Complete Works of Ralph Waldo Emerson, vol. 11, Houghton Mifflin, 1904, pp. 151-76.

Galli, Carlo. La Guerra Globale. Laterza, 2002.

Girard, René. Things Hidden Since the Foundation of the World. Stanford University Press, 2002.

------. Violence and the Sacred. Johns Hopkins UP, 1977.

Gougeon, Len. Virtue's Hero: Emerson, Antislavery, and Reform. $\mathrm{U}$ of Ceorgia P, 2010.

Kessler, Clive. "Syed Hussein Alatas (1928-2007). Wise Muslim Rationalist, Culturally Grounded Cosmopolitan." Akademika, vol. 73, 2008, pp. 127-38. 
Mariani, Giorgio. Waging War on War. Peacefighting in American Literature. U of Illinois P, 2015.

Mazzi, Enzo. Cristianesimo ribelle. Manifestolibri, 2002.

Melville, Herman. Moby-Dick. Edited by Hershel Parker and Harrison Hayford. Norton, 2002.

Moretti, Franco. Signs Taken for Wonders. On the Sociology of Literary Forms. Verso, 1988.

Mouffe, Chantal. Agonistics. Thinking the World Politically. Verso, 2013.

Pollit, Katha. "Blowing Smoke." The Nation, Apr. 3, 2008, https:// www.thenation.com/article/blowing-smoke. Accessed 20 May 2020.

Polner, Murray, and Thomas E. Woods, Jr., editors. We Who Dared to Say No to War. American Antiwar Writing from 1812 to Now. Basic Books, 2008.

Read, James H. "The Limits of Self-Reliance: Emerson, Slavery, and Abolition." A Political Companion to Ralph Waldo Emerson, edited by Alan M. Levine and Daniel S. Malachuk, UP of Kentucky, 2011, pp. 152-84.

Richardson, Robert. Emerson: The Mind on Fire. U of California P, 1996.

Rosenwald, Lawrence, editor. War No More: Three Centuries of American Antiwar o Peace Writing. The Library of America, 2016.

Said, Edward W. Culture and Imperialism. Vintage, 1994.

Stellato, Jesse, editor. Not in Our Name. American Antiwar Speeches, 1846 to the Present. Pennsylvania State UP, 2012.

Walzer, Michael. Just and Unjust Wars: A Moral Argument with Historical Illustrations. Basic Books, 1977.

Wink, Walter. Engaging the Powers: Discernment and Resistance in a World of Domination. Fortress, 199 
